\title{
Repeated allergen exposure enhances excitatory nonadrenergic noncholinergic nerve-mediated bronchoconstriction in sensitized guinea-pigs
}

\author{
N. Kageyama, M. Ichinose, A. Igarashi, M. Miura, H. Yamauchi, \\ Y. Sasaki, J. Ishikawa, M. Tomaki, K. Shirato
}

Repeated allergen exposure enhances excitatory nonadrenergic noncholinergic nervemediated bronchoconstriction in sensitized guinea-pigs. N. Kageyama, M. Ichinose, A. Igarashi, M. Miura, H. Yamauchi, Y. Sasaki, J. Ishikawa, M. Tomaki, K. Shirato. ( ERS Journals Ltd 1996.

ABSTRACT: The effect of repeated allergen inhalation challenge on the airway excitatory nonadrenergic noncholinergic (e-NANC) nerve-mediated bronchoconstrictor response was studied in ovalbumin (OA) sensitized guinea-pigs.

Three weeks after sensitization, $O A$ inhalation, $0.03 \%$ for 3 min (challenged group), or saline inhalation (control group) was repeated every day for 4 weeks. The e-NANC nerve function was examined in vitro by means of isometric tension measurement of main bronchi. After pretreatment with atropine $\left(1^{-6} \mathrm{M}\right)$ and propranolol $\left(1^{-6} \mathrm{M}\right)$, we performed electrical field stimulation (EFS) or exogenous neurokinin A (NKA) administration.

In the challenged group, EFS-induced main bronchial contraction was significantly greater than that of the control group $(p<0.05$ or $p<0.01)$, but exogenous NKA-mediated responses were almost the same in both groups. The e-NANC-induced main bronchial contractions after EFS were enhanced by pretreatment with the neutral endopeptidase inhibitor, phosphoramidon, to the same degree in the control and challenged groups, indicating that the peptide degradation mechanisms were not impaired even in the challenged group. Substance $\mathbf{P}$ immunoreactivities in the lung of the challenged group were significantly higher than those of the control group.

These results suggest that chronic airway inflammation after repeated allergen challenge increases excitatory nonadrenergic noncholinergic nerve function, possibly by enhancing sensory neuropeptide production and/or release.

Eur Respir J., 1996, 9, 1439-1444.
First Department of Internal Medicine, Tohoku University School of Medicine, Sendai, Japan.

Correspondence: K. Shirato

First Department of Internal Medicine Tohoku University School of Medicine 1-1 Seiryo-machi

Aoba-ku

Sendai $980-77$

Japan

Keywords: Airway inflammation antigen

asthma

neutral endopeptidase

substance P

Received: July 101995

Accepted after revision January 251996
In the airways, two excitatory neural mechanisms, namely cholinergic and nonadrenergic noncholinergic (NANC) mechanisms, have been reported [1]. The excitatory NANC (e-NANC) response is due to the antidromic release of tachykinins from sensory nerves [2]. Hyperfunction of this mechanism may be involved in the pathogenesis of asthma, as indicated by its various actions, such as bronchoconstriction [3], mucus secretion [4], and airway microvascular leakage [5], which are commonly observed in the airways in this disease. Bradykinin inhalation causes bronchoconstriction largely via neural reflex mechanisms [6], and the effect is obvious in asthmatic patients but not in nonasthmatic subjects [7]. Recently, we demonstrated that a tachykinin receptor antagonist inhibits bradykinin-induced airway narrowing in asthmatics, suggesting that the response can be attributed to endogenous tachykinins, presumably released from sensory nerves [8]. Taken together, this evidence suggests that e-NANC nerve function is enhanced in asthmatic airways.

A recent report showed that acute antigen challenge can potentiate e-NANC nerve-mediated tracheal contraction in guinea-pigs via the effect of histamine, which is released after the allergic reaction, presumably at the airway smooth muscle level [9]. However, the effect of repeated allergen exposure, which may more closely reflect the asthmatic airways, on airway e-NANC nerve function is still unknown. Therefore, the aim of this study was to elucidate whether repeated allergen challenge can increase e-NANC nerve function in sensitized guineapig airways. Excitatory-NANC nerve function was assessed by measuring the main bronchial contraction after electrical field stimulation (EFS) in control and repeated allergen inhaled groups.

When the e-NANC nerve function was enhanced, in order to assess how the e-NANC nerve function increased, the following experiments were performed. Firstly, to examine the response at the smooth muscle level, the main bronchial contraction was examined after exogenous neurokinin A (NKA), which is the main neurotransmitter for the bronchoconstrictor response, in both groups. Secondly, to examine the possible involvement of 
the neurotransmitter degradation mechanism, the e-NANC nerve-induced bronchial contractile response was assessed with or without phosphoramidon, an inhibitor of neutral endopeptidase, which is the main degradative enzyme for tachykinins. Thirdly, the substance P content in the lungs was measured in both groups to assess whether allergen challenge increased the e-NANC neurotransmitter content.

\section{Materials and methods}

\section{Animals}

Male Dunkin-Hartley guinea-pigs (200-250 g; n=55) were actively sensitized on two consecutive days by subcutaneous injection of $10 \mu \mathrm{g}$ ovalbumin (OA) dissolved in $0.5 \mathrm{~mL}$ of saline containing $\mathrm{Al}(\mathrm{OH})_{3} 100 \mathrm{mg}$ [10]. Three weeks after the sensitization procedure the animals were challenged every day with an aerosol saline (control group; $\mathrm{n}=28$ ) or $0.03 \%$ ovalbumin (challenged group; $n=27$ ) for 3 min during 4 weeks. All animals were placed in a plexiglass exposure chamber $(24.5 \times$ $40.5 \times 15.0 \mathrm{~cm})$ into which aerosol or saline was delivered with an ultrasonic nebulizer (output $0.8 \mathrm{~mL} \cdot \mathrm{min}^{-1}$ ).

\section{Tissue preparation for contraction study}

On the day after the final inhalation challenge (saline or OA), the animals were anaesthetized with urethane (2 $\mathrm{g} \cdot \mathrm{kg}^{-1}, i . p$.). The main bronchi were removed and placed in a $10 \mathrm{~mL}$ tissue bath containing Krebs-Henseleit solution (mM): $\mathrm{NaCl} 118, \mathrm{KCl} 5.9, \mathrm{MgSO}_{4} 1.2, \mathrm{CaCl}_{2} 2.5$, $\mathrm{NaH}_{2} \mathrm{PO}_{4} 1.2, \mathrm{NaHCO}_{3} 25.5$ and glucose 5.6, maintained at $37^{\circ} \mathrm{C}$ and bubbled with $95 \% \mathrm{O}_{2}, 5 \% \mathrm{CO}_{2}, \mathrm{pH}$ 7.4. Indomethacin $\left(10^{-5} \mathrm{M}\right)$ was present throughout the ex-periment in order to prevent the production of cyclooxygenase products, which may influence airway tone [11]. All the tissues were connected to a pressure transducer (UL-10GR; Minebea Co. Ltd, Tokyo, Japan) for the measurement of changes in isometric tension, and responses were recorded on a polygraph (Rectigraph-8K, NEC San-ei, Tokyo, Japan). An initial tension of $0.5 \mathrm{~g}$ was applied to main bronchi, which was found to be optimal for measuring changes in tension.

After pretreatment with atropine $\left(10^{-6} \mathrm{M}\right)$ and propranolol $\left(10^{-6} \mathrm{M}\right)$, EFS was delivered by two platinum wires connected to a stimulator (Electronic Stimulator; Nihon Kohden, Tokyo, Japan) and a unity gain inverting amplifier. Biphasic square wave impulses of supramaximal voltage $(50 \mathrm{~V})$ and $0.5 \mathrm{~ms}$ pulse duration were applied for $15 \mathrm{~s}$ every $20 \mathrm{~min}$ at frequencies ranging $1-32 \mathrm{~Hz}$ to main bronchi isolated from control $(n=5)$ or challenged animals $(n=5)$. In another group (control $n=5$; challenged $n=5$ ), frequency-response curves were obtained in the presence or absence of phosphoramidon $\left(10^{-5}\right.$ $\mathrm{M})$. The dosage of atropine, propranolol and phosphoramidon was chosen according to previous reports [1214].

Cumulative concentration-response curves to NKA $\left(10^{-10}\right.$ to $\left.3 \times 10^{-6} \mathrm{M}\right)$ were also obtained in main bronchi (control $n=10$; challenged $n=10$ ) with or without epithelium. Epithelial removal was performed by gently rubbing the luminal surface with a cotton wool swab.

\section{Quantification of substance $P$}

In other guinea-pigs, the thorax was opened and a blunt-ended, 13-gauge needle was inserted directly into the pulmonary artery, and blood was expelled through an incision in the left atrium at $30 \mathrm{mmHg}$ pressure, and then the needle was passed through a left ventriculotomy into the aorta. The ventricles were cross-clamped and blood was expelled through an incision in the right atrium at $80 \mathrm{mmHg}$ pressure with about $100 \mathrm{~mL}$ saline (pH 5.5) until the perfusate was clear. The lungs were then removed and the unilateral lung parenchyma was frozen in liquid nitrogen for the quantification of substance $\mathrm{P}$ (SP) (control group $n=8$; challenged group $n=7$ ). The frozen parenchyma was stored at $-70^{\circ} \mathrm{C}$ until use.

The weighed samples were diluted with $4 \%$ acetic acid (pH 4.0) to a final-volume of $50 \mathrm{~mL}$, homogenized and centrifuged at $40,000 \times \mathrm{g}$ for $30 \mathrm{~min}$. The supernatant obtained was loaded on a reversed-phase Sep-Pak C18 cartridge column. After washing with $20 \mathrm{~mL}$ of $80 \%$ acetic acid ( $\mathrm{pH} \mathrm{4.0)}$ and $20 \mathrm{~mL}$ of distilled water, each sample tube was eluted with $2 \mathrm{~mL}$ of $80 \%$ acetonitrile in $0.1 \%$ trifluoroacetic acid. Eluates were concentrated by spin-vacuum evaporation, lyophilized and dissolved with $0.15 \mathrm{~mL}$ of assay buffer $(50 \mathrm{mM}$ phosphate buffer $\mathrm{pH} 7.2$, containing $3.7 \mathrm{mg} \cdot \mathrm{mL}^{-1}$ ethylenediamine tetraacetic acid (EDTA) and $0.5 \%$ bovine serum albumin (BSA)). One tenth of a millilitre of the dissolved preparation was subjected to further radioimmunoassay (RIA) for SP. RIA for SP was performed using ${ }^{125}$ I-labelled SP and anti-SP rabbit serum. One tenth of a millilitre of the sample was mixed with $0.5 \mathrm{~mL}$ assay buffer, $0.1 \mathrm{~mL}$ antiserum and $0.1 \mathrm{~mL}{ }^{125} \mathrm{I}-\mathrm{SP}$ and left at $4^{\circ} \mathrm{C}$ for $24 \mathrm{~h}$. One fifth of a millilitre of dextran/charcoal suspension ( $0.2 \%$ dextran and $2 \%$ activated charcoal in assay buffer) was added to the reaction mixture and centrifuged at $2,000 \times \mathrm{g}$ for $10 \mathrm{~min}$. The radioactivity in the supernatant was measured by a $\gamma$-counter. The SP content (fmol.g-1 tissue) was calculated and differences between the two groups (control $n=8$; challenged $n=7$ ) compared. In this system, the sensitivity of immunoassayable SP was greater than $1 \mathrm{fmol} \cdot \mathrm{mL}^{-1}$.

\section{Drugs}

The following drugs were used: acetylcholine chloride (Daiichi Pharmaceutical Co. Ltd, Osaka, Japan); histamine dihydrochloride, acetic acid, acetonitrile, trifluoroacetic acid, dextran and activated charcoal (Wako Pure Chemical Industries Ltd, Osaka, Japan); indomethacin (Sumitomo Chemical Co., Osaka, Japan); atropine sulphate (Tanabe Pharmaceutical Co. Ltd, Osaka, Japan); propranolol hydrochloride (Imperial Chemical Industries plc., Macclesfield, UK); neurokinin A (Peptide Institute Inc., Osaka, Japan); phosphoramidon, urethane, ovalbumin and EDTA (Sigma Chemical Co., St. Louis, MO, USA); ${ }^{125}$ I-labelled substance $\mathrm{P}$ and anti-substance $\mathrm{P}$ rabbit serum (Amersham International plc., Amersham, UK).

\section{Statistical analysis}

Bronchial contraction was expressed as a percentage of the maximum tissue response to histamine $\left(10^{-3} \mathrm{M}\right)$. Curves were compared by two-way repeated-measures 


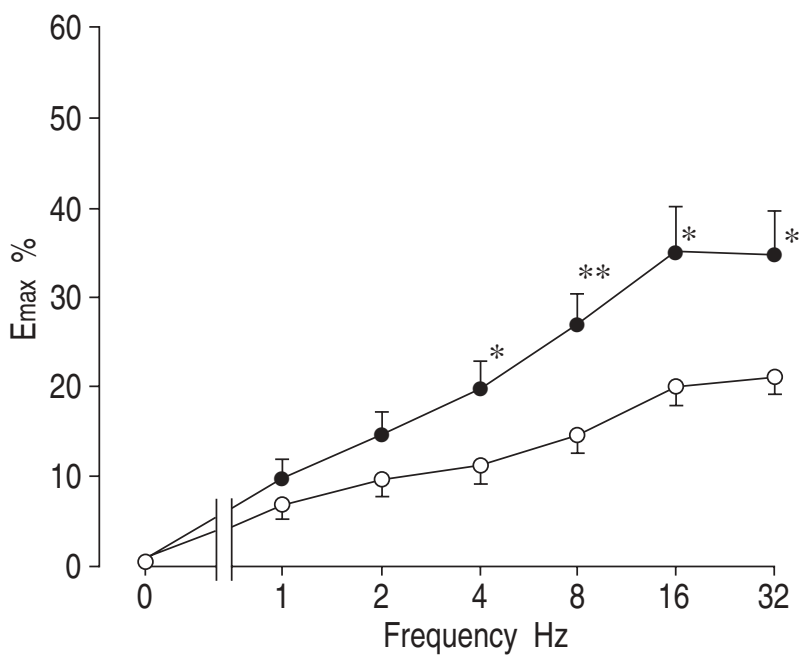

Fig. 1. - Effects of repeated inhalation challenge on e-NANC nervemediated bronchial contraction from repeated saline (-O-) or repeated ovalbumin challenged (-—) guinea-pigs. Contractile responses were elicited by electrical field stimulation (EFS), $50 \mathrm{~V}, 0.5 \mathrm{~ms}, 1-32$ $\mathrm{Hz}$ for $15 \mathrm{~s}$, in the presence of indomethacin $\left(10^{-5} \mathrm{M}\right)$, atropine $\left(10^{-6}\right.$ $\mathrm{M})$ and propranolol $\left(10^{-6} \mathrm{M}\right)$ and expressed as percentages of maximal responses to histamine $\left(10^{-3} \mathrm{M}\right)($ Emax $)$ in each preparation. Each point represents mean \pm SEM of five animals. Differences between two groups were compared using ANOVA and followed by Student's t-test for unpaired data. *: $\mathrm{p}<0.05 ; * *: \mathrm{p}<0.01$ compared with the values of control group. eNANC: excitatory nonadrenergic noncholinergic; ANOVA: analysis of variance.

analysis of variance (ANOVA). The differences at individual concentrations or frequency points were analysed by Student's t-test. The maximal contractile response to the highest concentration of NKA was expressed as a percentage of the maximal contraction to histamine $\left(10^{-3}\right.$ M). The concentrations producing $20 \%$ and $40 \%$ of the maximal contractile (Emax) effect induced by histamine $\left(10^{-3} \mathrm{M}\right)(\mathrm{EC} 20$ and $\mathrm{EC} 40$, respectively) were obtained from individual concentration-response curves of each tissue, and the geometric mean of EC20 or EC40 with $95 \%$ confidence interval $(95 \% \mathrm{CI})$ was calculated in each group. Similarly, the frequency producing $50 \%$ of the maximal contractile effect induced by histamine $\left(10^{-3} \mathrm{M}\right)$ (EF50) was obtained from individual frequency-response curves of each tissue and the mean of EF50 with 95\% CI was calculated in each group. Comparisons of EC20, EC40, Emax and EF50 between groups were performed using the Mann-Whitney U-test. The SP contents in the lungs were compared by Mann-Whitney U-test. The differences were considered significant at a p-value less than 0.05 . Data are presented as mean \pm SEM.

\section{Results}

Effects of repeated allergen exposure on airway smooth muscle contraction

In the presence of atropine and propranolol (both $10^{-6}$ $\mathrm{M})$, EFS of guinea-pig bronchial rings gave frequencyrelated e-NANC bronchoconstrictor responses. These contractile responses were significantly greater in the repeated allergen challenged group than in the control (repeated saline challenged) group at the frequency of 4, 8,16 and $32 \mathrm{~Hz}(\mathrm{p}<0.05)$ (fig. 1). Maximal contraction after e-NANC nerve stimulation was significantly greater
Table 1. - Effect of repeated antigen exposure on the e-NANC nerve-mediated muscle contraction

\begin{tabular}{ccc}
\hline & Control & Challenged \\
& $\mathrm{n}=5$ & $\mathrm{n}=5$ \\
\hline mmax $^{\#} \%$ & $22 \pm 2$ & $38 \pm 5^{*}$ \\
EF50 Hz & 2.8 & 3.7 \\
$95 \% \mathrm{CI}$ & $(2.4-3.4)$ & $(3.5-3.8)$ \\
\hline
\end{tabular}

\#: mean士SEM. Emax: maximal contractile response to EFS as a percentage of the contraction to histamine $\left(10^{-3} \mathrm{M}\right)$; EF50: the frequencies producing $50 \%$ of Emax; e-NANC: excitatory nonadrenergic noncholinergic; 95\% CI: 95\% confidence interval; EFS: electrical field stimulation. *: p $<0.05$ (Mann-Whitney Utest).

in the challenged group ( $38 \pm 5 \%)$ than in the control group $(22 \pm 2 \%)$, whereas EF50 values were not significantly different between the groups (table 1). Pretreatment with phosphoramidon $\left(10^{-5} \mathrm{M}\right)$ significantly shifted the frequency-response curve after EFS to an almost similar degree in the control and challenged groups $(\mathrm{p}<0.05$ for both) (fig. 2).
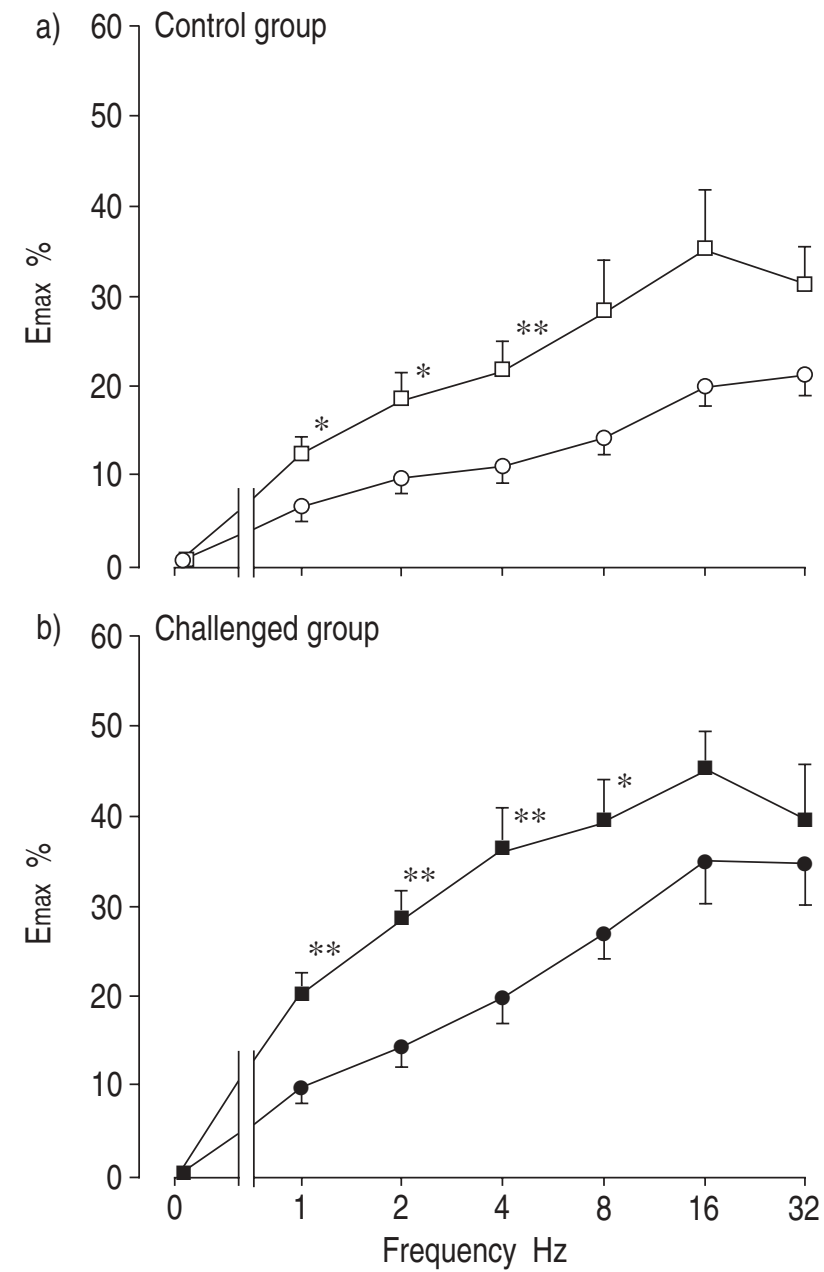

Fig. 2. - Effects of phosphoramidon on e-NANC nerve-mediated contraction of isolated main bronchi from: a) repeated saline; or b) repeated ovalbumin challenged animals, in the absence (circles) or presence (squares) of phosphoramidon $\left(10^{-5} \mathrm{M}\right)$. Contractile responses were elicited as described in fig. 1 legend. Values are mean士sEM of five animals. Differences were compared using ANOVA and followed by Student's t-test. Significant differences from control values are *: $\mathrm{p}<0.05$; **: $\mathrm{p}<0.01$. For definitions see legend to table 1 . 
Table 2. - Exogenous NKA-induced bronchial contraction and the effect of epithelial removal

\begin{tabular}{lccc}
\hline & $\begin{array}{c}\mathrm{EC} 20 \\
\mathrm{nM}\end{array}$ & $\begin{array}{c}\mathrm{EC} 40 \\
\mathrm{nM}\end{array}$ & $\begin{array}{c}\text { Emax } \\
\%\end{array}$ \\
\hline $\begin{array}{l}\text { Control } \\
\text { With epithelium } \\
(\mathrm{n}=5)\end{array}$ & $\begin{array}{c}36.9 \\
(14.5-95.5) \\
2.86^{*}\end{array}$ & $\begin{array}{c}(383-1630) \\
16.2 * *\end{array}$ & $82 \pm 4 * *$ \\
$\begin{array}{l}\text { Without epithelium } \\
(\mathrm{n}=5)\end{array}$ & $\begin{array}{c}(1.8-4.6) \\
(10.6-24.6)\end{array}$ & \\
$\begin{array}{l}\text { Challenged } \\
\text { With epithelium } \\
(\mathrm{n}=5)\end{array}$ & $\begin{array}{c}27.3 \\
(16.9-44.1) \\
3.06^{* *}\end{array}$ & $\begin{array}{c}213 \\
(104-436)\end{array}$ & $63 \pm 4$ \\
$\begin{array}{l}\text { Without epithelium } \\
(\mathrm{n}=5)\end{array}$ & $(1.8-5.3)$ & $(10-34.4)$ & $81 \pm 7^{* *}$ \\
\hline
\end{tabular}

95\% CI values are in parentheses. EC20 and EC40: the concentration producing $20 \%$ and $40 \%$ of maximal contractile response to histamine $\left(10^{-3} \mathrm{M}\right)$, respectively; Emax: maximal contractile responses to the exogenous NKA $\left(3 \times 10^{-6} \mathrm{M}\right)$ expressed as a percentage of contraction to histamine $\left(10^{-3} \mathrm{M}\right)$. Significant differences from values with epithelium are indicated, *: $\mathrm{p}<0.05 ; * *: \mathrm{p}<0.01$. There was no significant difference between control and challenged group in $\mathrm{EC} 20, \mathrm{EC} 40$, or Emax values. NKA: neurokinin A; $95 \%$ CI: 95\% confidence interval.

Exogenous NKA $\left(10^{-10}-10^{-6} \mathrm{M}\right)$ caused dose-related bronchial contraction in the control and challenged groups. There was no significant difference between the groups in EC20, EC40 or Emax values (table 2). Epithelial removal significantly enhanced NKA-induced contractile responses at $10^{-8}$ to $3 \times 10^{-6} \mathrm{M}$ in the control group $(\mathrm{p}<0.01$ or $\mathrm{p}<0.001$ ), and at $10^{-9}$ to $3 \times 10^{-6} \mathrm{M}$ in the challenged group $(\mathrm{p}<0.05$ or $\mathrm{p}<0.01$ ) (fig. 3 ). Table 2 shows a significant change in EC20, EC40 and Emax values in both groups (table 2), with epithelial removal.

\section{SP quantification in the lungs}

SP contents in the lung are shown figure 4. The lung SP contents of the repeated allergen challenged group $\left(51.2 \pm 8.4 \mathrm{fmol} \cdot \mathrm{g}^{-1}\right.$ tissue) were significantly higher than those of the control group $\left(24.5 \pm 3.7 \mathrm{fmol} \cdot \mathrm{g}^{-1}\right.$ tissue $)$ $(\mathrm{p}<0.05)$

\section{Discussion}

These results indicate that repeated allergen inhalation potentiates e-NANC nerve-mediated contraction to EFS in isolated main bronchi from sensitized guineapigs. In the e-NANC bronchoconstriction, NKA is considered the major neurotransmitter because airway smooth muscle contraction is mainly via neurokinin-2 $\left(\mathrm{NK}_{2}\right)$ receptors [15], and NKA has high affinity for these receptors [16]. In the present study, exogenously applied NKA-induced bronchial contractile responses were not significantly different between the control and repeated challenged groups, suggesting that the response to NKA at the airway smooth muscle level is not changed by repeated allergen exposure.

In the present study, SP-immunoreactivity in the lungs was significantly higher in the allergen challenged groups than in the control groups, indicating that upregulation
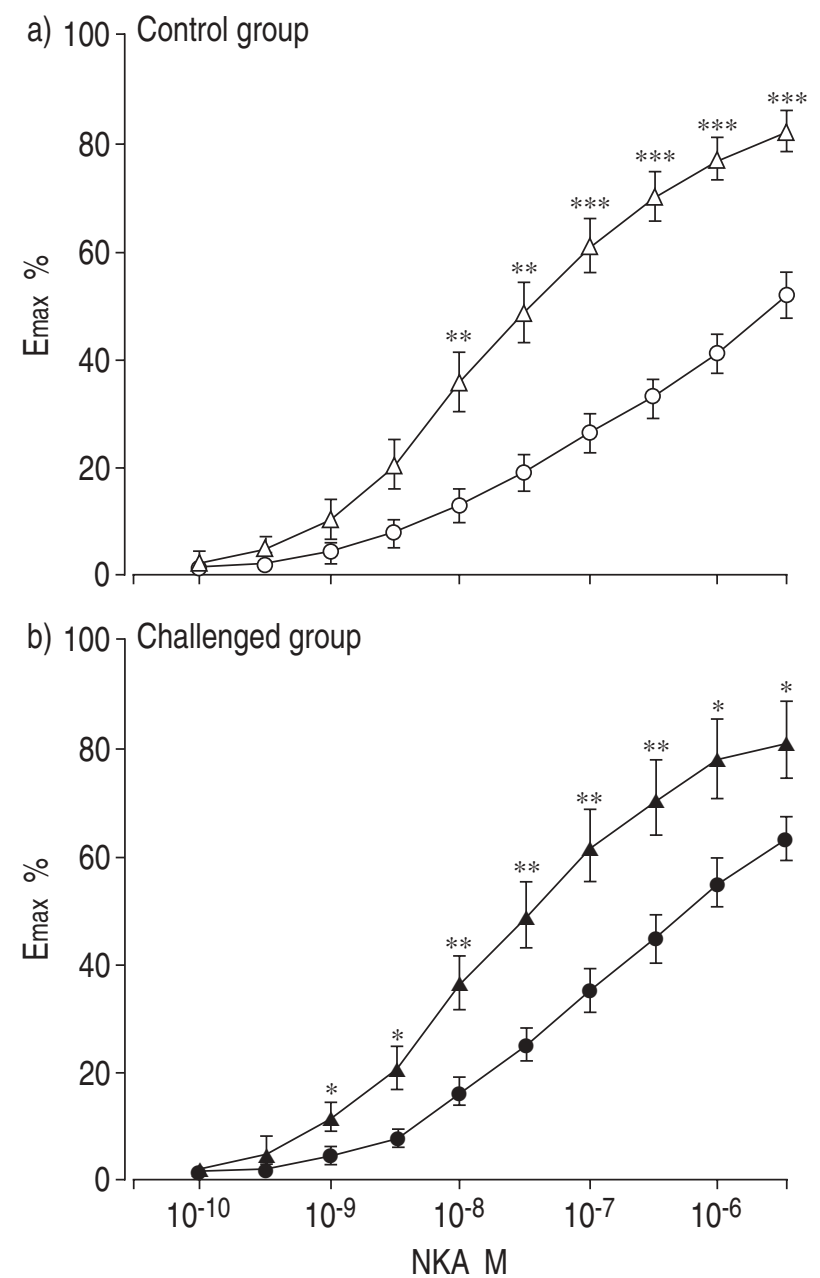

Fig. 3. - Neurokinin A (NKA, $10^{-10}$ to $3 \times 10^{-6} \mathrm{M}$ ) induced contraction of: a) repeated saline with $(-\infty-)$ ) or without epithelium $(\triangle-)$; and b) ovalbumin inhalation group with (- - ) or without epithelium $(-\mathbf{\Delta}-)$ in the presence of indomethacin $\left(10^{-5} \mathrm{M}\right)$, atropine $\left(10^{-6} \mathrm{M}\right)$ and propranolol $\left(10^{-6} \mathrm{M}\right)$. Each point represents mean \pm SEM of five animals. Differences between the two curves with or without epithelium in each group were compared using analysis of variance (ANOVA) and followed by Student's t-test for unpaired data. *: $\mathrm{p}<0.05$; **: $\mathrm{p}<0.01$; $* * *: \mathrm{p}<0.001$, compared with the values of intact epithelium. Emax: maximal contractile response to the exogenous NKA expressed as a percentage of contraction to histamine $\left(10^{-3} \mathrm{M}\right)$.

of this peptide may have occurred by repeated allergen exposure. Neuropeptide expression is regulated, in part, by interactions with specific immunomodulators, such as interleukin-1 $\beta$ (IL-1 $\beta$ ) [17-19], which may be released from alveolar macrophages, endothelial cells and eosinophils after allergen exposure [20-23]. In a rat cervical ganglion culture model, the level of SP and the expression of tachykinin precursor preprotachykinin messenger ribonucleic acid (mRNA) were increased by IL-1 $\beta$ [17]. In addition, nerve growth factor (NGF), which is also essential both for the development and function of peptidergic sensory neurons [24-26], is upregulated by IL-1 [27]. Thus, it is possible that repeated allergen exposure causes IL-1 release into the airways, and that the NGF subsequently synthesized by IL-1 increases the sensory neuropeptides.

In immunohistochemical study, it has been shown that, in asthmatic airways, there is an increase in SP-immunoreactive nerves in airways, particularly in the submucosal 


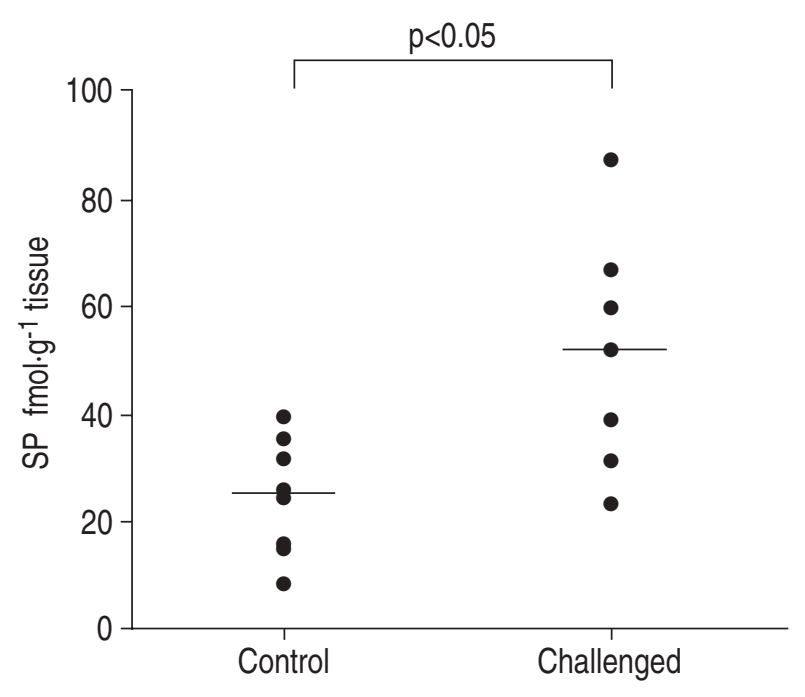

Fig. 4. - Substance P (SP) content (fmol.g-1 tissue) in guinea-pig lung tissue in repeated saline exposed (control, $n=8$ ) or repeated allergen challenged animals (challenged, $n=7$ ). Bars indicate mean values. Differences between the two groups were compared by Mann-Whitney U-test.

area [28]. Furthermore, there were higher baseline levels of SP-like immunoreactivity as well as increases after allergen provocation in the bronchoalveolar lavage fluid of allergic subjects but not in nonallergic controls [29]. We have also recently reported that the SP content level in induced sputum is higher in asthmatic subjects than in normal controls [30]. This evidence suggests that SP seems to play an important role in asthmatic airway inflammation, although two reports have shown that there was no excess of SP-immunoreactive nerves in asthmatic airways compared with nonasthmatic airways $[31,32]$. Nevertheless, taken together, the former evidence and our present results suggest that chronic allergic airway reaction may enhance the SP-mediated, i.e. neurogenic, response, and may exaggerate the airway inflammation.

Recently, ELLIS and UNDEM [9] reported that antigen enhanced e-NANC nerve-mediated tracheal contraction in guinea-pigs in vitro. Because histamine $\mathrm{H}_{1}$-receptor antagonist reversed the potentiation, they concluded that antigen challenge releases histamine which acts via $\mathrm{H}_{1}$ receptors to enhance e-NANC contractions due to the release of tachykinins from sensory nerves. This presynaptic modulation mechanism may be involved in the potentiation of the e-NANC nerve-mediated response observed in the present study. However, in our study, repeated allergen inhalation potentiated the e-NANC contraction without affecting the threshold of the nerve, because the EF50 values for nerve stimulation were not significantly different in control and challenged animals (table 1). Therefore, it is likely that the potentiation of e-NANC nerve-mediated responses observed in the present study is due to the enhanced sensory neuropeptide production and subsequent increased neuropeptide release after nerve stimulation.

Another possible mechanism which may cause the airway e-NANC nerve hyperfunction is a change in the tachykinin degradation system. In the airways, the tachykinins SP and NKA, are mainly degradated by neutral endopeptidase (NEP), which is found in epithelium, submucosal glands, nerves, and smooth muscle [33]. In fact, NEP inhibitors potentiate electrically- and capsaicin-induced e-NANC contraction in guinea-pig bronchi [34-36]. Therefore, it is possible that repeated allergen inhalation increases e-NANC nerve-mediated bronchial contraction via downregulation of the NEP [37]. However, in the present study, exogenously applied NKA-induced contractile responses were almost the same in the control and repeated allergen challenged groups. Furthermore, the NEP inhibitor phosphoramidon potentiated the e-NANC nervemediated contractile response to the same degree in both groups, and epithelium (which is abundant in NEP) removal also enhanced the exogenous NKA-mediated responses similarly in the two groups. Therefore, the possibility that tachykinin degradation enzyme dysfunction contributes to the enhancement of the e-NANC contractile responses is unlikely.

The SP levels measured in this study were relatively lower than those of a previous study [38]. The exact reason for the discrepancy is unclear. We measured SP content in the lung without heat-inactivation of peptidases or administration of peptidase inhibitors, such as NEP and angiotensin-converting enzyme. Therefore, SP degradation mechanisms might explain the low SP levels in the present study. However, even with this technique, the SP levels measured in this study were high enough for the sensitivity of the assay system. Therefore, we believe that the data obtained in the present study are reliable.

In summary, we have demonstrated that repeated allergen inhalation can increase excitatory nonadrenergic noncholinergic neural function, presumably by enhancing neurotransmitter production and/or release. Neuropeptides released from excitatory nonadrenergic noncholinergic nerves have potent actions, including airway smooth muscle contraction, secretion, microvascular leakage and a priming effect for eosinophils, which are compatible with the pathogenesis of asthma. Thus, it is possible that chronic allergic airway inflammation occurs not only via inflammatory cell mechanisms but also via neurogenic mechanisms. Therefore, prevention both of allergic and neurogenic responses may be beneficial in asthma therapy.

\footnotetext{
Acknowledgements: The authors thank B. Bell for reading the manuscript.
}

\section{References}

1. Barnes PJ. Neural control of human airways in health and disease. Am Rev Respir Dis 1986; 134: 1289-1314.

2. Barnes PJ . Asthma as an axon reflex. Lancet 1986; i: 242-245.

3. Lundberg JM, Lundblad L, Änggård A, et al. Bioactive peptides in capsaicin-sensitive C-fiber afferents of the airways: functional and pathophysiological implications. In: Kaliner M, Barnes PJ, eds. The Airways: Neural Control in Health and Disease. New York, Marcel Dekker, 1987; pp. 417-445.

4. Peatfield AC, Richardson PS. Evidence for noncholinergic, nonadrenergic nervous control of mucus secretion into the cat trachea. J Physiol 1983; 342: 335-345.

5. Lundberg JM, Saria A, Brodin E, Rosell S, Folkers K. A substance $P$ antagonist inhibits vagally-induced increase 
in vascular permeability and bronchial smooth muscle contraction in the guinea-pig. Proc Natl Acad Sci USA 1983; 80: 1120-1124.

6. Ichinose M, Belvisi MG, Barnes PJ. Bradykinin-induced bronchoconstriction in guinea-pig in vivo: role of neural mechanisms. J Pharmacol Exp Ther 1990; 253: 594599.

7. Fuller RW, Dixon CMS, Cuss FMC, Barnes PJ. Bradykinin-induced bronchoconstriction in humans: mode of action. Am Rev Respir Dis 1987; 135: 176-180.

8. Ichinose M, Nakajima N, Takahashi T, Yamauchi H, Inoue $\mathrm{H}$, Takishima $\mathrm{T}$. Protection against bradykinininduced bronchoconstriction in asthmatic patients by neurokinin receptor antagonist. Lancet 1992; 340: 1248-1251.

9. Ellis JL, Undem BJ. Antigen-induced enhancement of noncholinergic contractile responses to vagus nerve and electrical field stimulation in guinea-pig isolated trachea. J Pharmacol Exp Ther 1992; 262: 646-653.

10. Andersson P. Antigen-induced bronchial anaphylaxis in actively sensitized guinea-pigs. Allergy 1980; 35: 65-71.

11. Undem BJ, Myers AC, Barthlow H, Weinreich D. Vagal innervation of guinea-pig bronchial smooth muscle. $J$ Appl Physiol 1990; 69: 1336-1346.

12. Lundberg JM, Saria A, Brodin E, Rosell S, Folkers K. A substance $P$ antagonist inhibits vagally-induced increase in vascular permeability and bronchial smooth muscle contraction in the guinea-pig. Proc Natl Acad Sci USA 1983; 80: 1120-1124.

13. Taylor SM, Paré PD, Schellenberg RR. Cholinergic and nonadrenergic mechanisms in human and guinea-pig airways. J Appl Physiol: Respirat Environ Exercise Physiol 1984; 56: 958-965.

14. Naline E, Devillier P, Drapeau G, et al. Characterization of neurokinin effects and receptor selectivity in human isolated bronchi. Am Rev Respir Dis 1989; 140: 679-686.

15. Barnes PJ, Baraniuk JN, Belvisi MG. State of the art: neuropeptides in the respiratory tract. Part I. Am Rev Respir Dis 1991; 144: 1187-1198.

16. Regoli D, Drapeau G, Dion S, D'Orléans-Juste P. Pharmacological receptors for substance $\mathrm{P}$ and neurokinins. Life Sci 1987; 40: 109-117.

17. Freidin M, Kessler JA. Cytokine regulation of substance P expression in sympathetic neurons. Proc Natl Acad Sci USA 1991; 88: 3200-3203.

18. Hart RP, Shadiack AM, Jonakait GM. Substance P gene expression is regulated by interleukin-1 in cultured sympathetic ganglia. J Neurosci Res 1991; 29: 282-291.

19. Hurst SM, Stanisz AM, Sharkey KA, Collins SM. Interleukin $1 \beta$-induced increase in substance $P$ in rat myenteric plexus. Gastroenterology 1993; 105: 1754-1760.

20. Borish L, Mascali JJ, Dishuck J, Beam WR, Martin RJ, Rosenwasser LJ. Detection of alveolar macrophagederived IL-1 $\beta$ in asthma: inhibition with corticosteroids. J Immunol 1992; 149: 3078-3082.

21. Del Pozo V, De Andres B, Martin E, et al. Murine eosinophils and IL-1: IL- $1 \alpha$ mRNA detection by in situ hybridization. Production and release of IL-1 from peritoneal eosinophils. J Immunol 1990; 144: 3117-3122.

22. Miossec P, Cavender D, Ziff M. Production of interleukin-1 by human endothelial cells. J Immunol 1986; 136: 2486-2491.
23. Marucha PT, Zeff RA, Kreutzer DL. Cytokine regulation of IL- $1 \beta$ gene expression in the human polymorphonuclear leukocyte. J Immunol 1990; 145: 2932-2937.

24. Otten U. Nerve growth factor and the peptidergic sensory neurons. Trends Phamacol Sci 1984; 5: 307-310.

25. Lindsay RM, Harmar AJ. Nerve growth factor regulates expression of neuropeptides genes in adult sensory neurons. Nature 1989; 337: 362-364.

26. Gilchrist CA, Morrison C, Harmar AJ. Regulation of preprotachykinin gene expression by nerve growth factor. In: Leeman SE, Krause JE, Lembeck F, eds. Substance P and related peptides: cellular and molecular physiology. Ann NY Acad Sci 1991; 632: 391-393.

27. Lindholm D, Heumann R, Meyer M, Thoenen H. Interleukin-1 regulates synthesis of nerve growth factor in nonneuronal cells of rat sciatic nerve. Nature 1987; 330: 658-659.

28. Ollerenshaw SL, Jarvis D, Sullivan CE, Woolcock AJ. Substance P immunoreactive nerves in airways from asthmatics and nonasthmatics. Eur Respir J 1991; 4: 673-682.

29. Nieber K, Baumgarten CR, Rathsack R, Furkert J, Oehme $\mathrm{P}$, Kunkel G. Substance $\mathrm{P}$ and $\beta$-endorphin-like immunoreactivity in lavage fluids of subjects with and without allergic asthma. J Allergy Clin Immunol 1992; 90: 646652.

30. Tomaki M, Ichinose M, Miura M, et al. Elevated substance $\mathrm{P}$ content in induced sputum from patients with asthma and patients with chronic bronchitis. Am J Respir Crit Care Med 1995; 151: 613-617.

31. Howarth PH, Djukanovic R, Wilson JW, Holgate ST, Springall DR, Polak JM. Mucosal nerves in endobronchial biopsies in asthma and nonasthma. Int Arch Allergy Appl Immunol 1991; 94: 330-333.

32. Howarth PH, Springall DR, Redington AE, Djukanovic R, Holgate ST, Polak JM. Neuropeptide-containing nerves in endobronchial biopsies from asthmatic and nonasthmatic subjects. Am Rev Respir Cell Mol Biol 1995; 13: 288-296.

33. Nadel JA. Neutral endopeptidase modulates neurogenic inflammation. Eur Respir J 1991; 4: 745-754.

34. Djokic TD, Nadel JA, Dusser DJ, Sekizawa K, Graf PD, Borson DB. Inhibitors of neutral endopeptidase potentiate electrically- and capsaicin-induced noncholinergic contraction in guinea-pig bronchi. J Pharmacol Exp Ther 1989; 248: 7-11.

35. Frossard N, Rhoden KJ, Barnes PJ. Influence of epithelium on guinea-pig airway responses to tachykinins: role of endopeptidase and cyclooxygenase. J Pharmacol Exp Ther 1989; 248: 292-298.

36. Sekizawa K, Tamaoki J, Nadel JA, Borson DB. Enkephalinase inhibitor potentiates substance P- and electricallyinduced contraction in ferret trachea. J Appl Physiol 1987; 63: 1401-1405.

37. Lilly CM, Kobzik L, Hall AE, Drazen JM. Effects of chronic airway inflammation on the activity and enzymatic inactivation of neuropeptides in guinea-pig lungs. J Clin Invest 1994; 93: 2667-2674.

38. Lundberg JM, Brodin E, Saria A. Effects and distribution of vagal capsaicin-sensitive substance $P$ neurons with special reference to the trachea and lungs. Acta Physiol Scand 1983; 119: 243-252. 